\title{
Nota
}

\section{ECONOMIC ARGUMENTS AND LEGAL REGULATIONS ON RITUAL SLAUGHTER IN POLAND ${ }^{1}$}

Fecha de recepción: 7 de junio de 2020

Fecha de aceptación: 20 de julio de 2020

ABSTRACT: When regulating ritual slaughter, we need to take into consideration issues related both to the protection of freedom of conscience and religion, the freedom of business activity, and the humane treatment of animals. The economic arguments have an influence on the way ritual slaughter is regulated and generally lead to departing from the original religious purpose of such legal regulations, in favour of protecting economic interests.

KEY WORDS: ritual slaughter; manifestation of religious freedom; freedom of economic activity.

" Department of Law on Religion. Faculty of Law, Canon Law and Administration. The John Paul II Catholic University of Lublin, Poland: konrad.dyda@gmail. com; ORCID: https://orcid.org/0000-0002-2061-7839

1 In September 2020, representatives of the governing party in Poland announced a proposal for a law limiting the possibility of ritual slaughter. This article - due to the time of its submission for printing - does not cover the issue of possible legislative work on this draft, referring to the legal status for August 2020. 


\section{Argumentos económicos y regulación jurídica del sacrificio ritual en Polonia}

RESUMEN: En la regulación del sacrificio ritual, deben tenerse en cuenta cuestiones relacionadas con la protección de la libertad de conciencia y religión, la libertad de actividad comercial y el trato humanitario a los animales. Los argumentos económicos influyen en la forma en que se regulan los sacrificios rituales y, en general, llevan a apartarse del propósito religioso original de esas normativas legales, en favor de la protección de los intereses económicos.

PALABRAS CLAVE: sacrificio ritual; manifestación de la libertad religiosa; libertad de actividad económica.

\section{INTRODUCTION}

The consumption of kosher meat is strongly rooted in some religious traditions, especially those originating in Judaism and Islam. At the same time, many consumers in Europe and throughout the world consider kosher meat to be a delicacy, and hence the production of such meat is a lucrative business. Economic and religious aspects are strongly interrelated here ${ }^{2}$. For this reason, when regulating ritual slaughter, we need to take into consideration issues related both to the protection of freedom of conscience and religion, the freedom of business activity, and the humane treatment of animals. The economic arguments have an influence on the way ritual slaughter is regulated and generally lead to departing from the original religious purpose of such legal regulations, in favour of protecting economic interests. Poland is a good case in point here.

Unfortunately, there is no detailed information on the scale of halal and kosher meat production in Poland. In fact, the only data available concerns the period when a heated legal and political controversy on the legality of ritual slaughter developed in Poland. Before a ban on ritual slaughter was introduced, Poland had been one of the largest exporters of kosher meat in Central and Eastern Europe ${ }^{3}$. It should be remembered that Jews and Muslims account for less than 0.15 of

2 See S. Vellenga. "Ritual Slaughter, Animal Welfare and the Freedom of Religion”. Journal of Religion in Europe 2 (2015): 210-234.

3 Polish ban on kosher slaughter of animals is overturned, https://www.bbc.com/ news/world-europe-30412551, (19.02.2020 r.). 
the population in Poland ${ }^{4}$. According to some estimates of kosher meat producers, there were 80 such businesses in Poland, with kosher meat accounting for approximately $10 \%$ of the annual meat exports in $2013^{5}$. Polish authorities openly admit that they do not collect such data. However, it is estimated that between 2015 and 2017 (i.e., after ritual slaughter had been re-legalised), kosher and halal meat exports to the EU internal market and to third countries accounted for respectively $14.6 \%, 17.1 \%$, and $17.6 \%$ of the total amount of beef exported from Poland ${ }^{6}$. In 2018, the opinion-forming media informed that the export of kosher beef constituted as much as approximately $30 \%$ of total beef exports ${ }^{7}$.

Thus, it can be stated that the export of kosher meat from Poland increased in recent years. This was accompanied by fierce disputes concerning legal regulations on ritual slaughter. These disputes developed between religious groups, business owners and animal rights defenders, mainly as a result of changes in the EU legislation. Anyway, in Poland, the formal possibility of cultivating religious practices based on ritual slaughter has led to a real opportunity - paradoxically contrary to Polish and EU law - of industrial production of this type of meat.

\section{RITUAL SLAUGHTER AS A MANIFESTATION OF RELIGIOUS FREEDOM IN THE INTERNATIONAL AND EU LAW}

Since ritual slaughter is a religious practice, it is protected under Article 9(1) of the European Convention for the Protection of Human Rights and Fundamental Freedoms. Also other international law regulations strengthen this thesis; e.g., Article 17(1) of the European Convention

${ }^{4}$ Wyznania religijne $w$ Polsce $w$ latach 2015-2018, Główny Urząd Statyczny, Warszawa 2019, s. 326.

5 Ubój rytualny: Zbiorowo przeciwko Skarbowi Państwa?, http://www.portalspozywczy.pl/mieso/wiadomosci/uboj-rytualny-zbiorowo-przeciwko-skarbowi-panstwa, 88839.html, (20.02.2020 r.).

6 Pismo Ministra Rolnictwa i Rozwoju Wsi do Marszałka Sejmu RP z dnia 29 marca 2018 r., http://orka2.sejm.gov.pl/INT8.nsf/klucz/658C47F2/\%24FILE/i20392-o1.pdf (20.02.2020 r.).

7 Ubój rytualny: ograniczenie może oznaczać straty, https://www.rp.pl/Dobra -osobiste/303269940-Uboj-rytualny-ograniczenie-moze-oznaczac-straty.html?cid (20.02.2020 r.). 
for the Protection of Animals for Slaughter, which authorises state parties to allow slaughtering animals without prior stunning in the case of "slaughtering in accordance with religious rituals», among others. In such cases, it must be ensured that animals are spared any avoidable pain or suffering (Article 17(2)) and in the case of the ritual slaughter of animals of the bovine species, they shall be restrained before slaughter by mechanical means (Article 13). Nonetheless, there is no doubt that freedom to manifest religion is not unrestricted, and thus the right to exercise this freedom in the form of ritual slaughter may be subject to limitations in accordance with the rules set out in Article 9 (2) of the European Convention.

Strasbourg case-law contains only two judgements on ritual slaughter. In the Audience Association Culturelle Israélite Cha'are Shalom ce Tsedet vs. France case (no 27417/95), the European Court of Human Rights, sitting as the Grand Chamber, ruled that restricting ritual slaughter by allowing it to be performed only in slaughterhouses and only by some religious bodies, did not violate Article 9 of the European Convention. In the said case, the French government refused the applicant association the permission to carry out ritual slaughter and stated, inter alia, that in fact it was not a religious association and it was not sufficiently representative of the Jewish community (it had circa 40.000 adherents, while similar organisations had even several times more members). It is worth pointing out that the applicant described itself as an entity representing «ultra-Orthodox» Jews, and questioned the correctness of ritual slaughter carried out by authorised organisations; which in turn deprived its members of the possibility to practice their religion.

In this judgment, the Court expressly confirmed that ritual slaughter was an aspect of practice of the Jewish religion and as such was protected under Article 9 of the Convention (\$73). However, ritual slaughter should be - «in the general interest» - regulated by state authorities (§74), and at the same time it must constitute a practice of religion (\$78). Freedom of religion is violated only when the followers are completely deprived of the possibility of eating meat from animals slaughtered in accordance with the religious prescriptions they consider applicable (§80). In this way, the Court explicitly excluded the possibility of performing ritual slaughter for commercial purposes, under the guise of exercising the right to religious freedom. 
That the second case regarding ritual slaughter: Verein gegen Tierfabriken vs. Switzerland (no. 48703/08) was not heard on the grounds of freedom of religion, but on the grounds of prohibition of discrimination (Article 14) and the freedom of expression (Article 10). The applicant was an association engaged in political activity and protection of animal rights. In their magazine published during the election campaign, they urged the public not to vote for politicians that approved of ritual slaughter. The Court found that by restricting the possibility of distributing the magazine, the postal operator did not violate the above mentioned guarantees.

At the EU level, ritual slaughter is currently regulated by Council Regulation (EC) No 1099/2009 of 24 September 2009 on the Protection of Animals at the Time of Killing. The fundamental principle implemented in this regulation is to spare animals unnecessary pain at the time of killing - by stunning them beforehand. At the same time, the Regulation recognized the member states the right to maintain in their law slaughter without stunning carried out in slaughterhouses in accordance with religious rites (recitals 18). The term "religious rite» is defined as a series of acts related to the slaughter of animals and prescribed by a religion (Article $2 \mathrm{~g}$ ). Slaughter without stunning must be done with a single cut of the throat with a sharp knife. Animals that are most commonly slaughtered under this procedure; i.e. of bovine, ovine and caprine species should be individually and mechanically restrained (recitals 43).

Pursuant to Article 4(4) of the regulation, slaughter without prior stunning of the animal may be carried out only by persons holding a certificate of competence for such operations (Article 7(2)). Moreover, animals slaughtered in this way must be restrained individually while ruminants must be restrained mechanically. The exception concerning ritual slaughter should be interpreted strictly, which means that it does not apply to obtaining meat for business purposes ${ }^{8}$. It should be remembered that protecting the legality of producing kosher food is not only an

8 Wojciech Brzozowski. “Ubój rytualny a Konstytucja RP”. In Aktualne problemy wolności myśli, sumienia i religii, edited by Piotr Stanisz, Anna Maria Abramowicz, Michał Czelny, Marta Ordon and Michał Zawiślak, 41-52. Lublin: Wydawnictwo KUL, 2015. 
expression of giving protection to religious freedom, but also it protects the rights of national and ethnic minorities ${ }^{9}$. These arguments are commonly raised, especially by the followers of Judaism in Poland ${ }^{10}$.

The principles of the Council Regulation underlie the legislation of European Union members, where animals as a rule are slaughtered after they have been stunned, with the exception of ritual slaughter ${ }^{11}$. Also in Polish doctrine it is argued that the exception of killing animals without prior stunning applies only to the slaughter of animals carried out in a slaughterhouse according to religious rites and for the purposes of religious practice. This, in turn, precludes performing such slaughter for economic purposes - even if it were to be performed in accordance with religious norms ${ }^{12}$. Hence, it should be concluded that trade in meat obtained in this way is only permitted to the extent of fulfilling religious needs.

The EU regulation No. 1099/2009 sets a minimum standard for the protection of slaughter animals. Under Article 26(1), member states were allowed to maintain more restrictive national regulations which were in force at the time this regulation came into force (i.e., 1 January 2013) and which aimed at ensuring more extensive protection of animals at the time of killing. To do so, member states were obliged to notify the Commission of such national rules. In the case of Poland, it was the controversy over the scope of implementing this EU provision that determined the way ritual slaughter is currently regulated.

9 See Pablo Lerne, Alfredo Mordechai Rebello. "The Prohibition of Ritual Slaughtering (Kosher Shechita and Halal) and Freedom of Religion of Minorities". Journal of Law and Religion 2 (2006): 1-62.

10 D. Dilefsky. "Polish Jews Fight Law on Religious Slaughter of Animals", https:// www.nytimes.com/2013/09/05/world/europe/polish-jews-fight-law-on-religiousslaughter-of-animals.html, (Consultado el 19.02.2020); "Polish ritual slaughter illegal, court rules", https://www.bbc.com/news/world-europe-20523809, (Consultado el 21.02.2020 r.).

${ }^{11}$ Carla Maria Zoethout. "Ritual Slaughter and the Freedom of Religion: Some Reflections on a Stunning Matterr”. Human Rights Quarterly 3 (2013): 660.

12 Ewa Łętowska, Monika Namysłowska, Mateusz Grochowski, Aneta Wiewiórowska-Domagalska. "Prawo UE o uboju zwierząt i jego polska implementacja: kolizje interesów i ich rozwiązanie (cz. I)”. Europejski Przegląd Sądowy 11 (2013): 15-16. 


\section{EVOLUTION OF LEGAL REGULATIONS ON RITUAL SLAUGH- TER IN POLAND}

The original version of the Act of 21 August 1997 on Animal Protection ${ }^{13}$ allowed slaughtering an animal without prior stunning while performing slaughter prescribed by «religious rites» (Article 34 (5)). This possibility, however, was not limited exclusively to rites following from the doctrine of religious groups with a regulated legal status. The provision was repealed under the Act of 6 June 2002 on amending the Act on Animal Protection on the grounds that provisions of the Polish law must conform with the EU Directive 93/11914. However, the directive, as well as the Council Regulation on this matter, did not prohibit ritual slaughter. Hence, this argument should be treated as an excuse to ban such slaughter.

In addition, the legislator in the 2002 amendment, authorised the Minister of Agriculture to determine - by way of regulation - the qualifications of persons authorised to perform slaughter and the acceptable methods of slaughtering and killing animals. The regulation was issued by the Minister of Agriculture and Rural Development on 9 September $2004^{15}$. Paragraph 8 (2) repealed the obligation to stun animals that were slaughtered in accordance with the religious rites of registered religious organisations. This, in turn, led to re-legalising unstunned slaughter - this time by way of an executive act and moreover, contrary to the law in force. For this reason, the Constitutional Tribunal in the judgment of 27 November $2012^{16}$ held that the said provision of the regulation was contrary to the Constitution ${ }^{17}$. It is worth noting that the Tribunal postponed

13 On the historical aspect of this issue see: Mieczysław Różański, Piotr Szymaniec. "Debata wokół zakazu uboju rytualnego w II Rzeczypospolitej Polskiej". Przegląd Sejmowy 1 (2020): 121-146.

${ }^{14}$ Uzasadnienie projektu ustawy o zmianie ustawy ochronie zwierząt, Druk Sejmowy 339, Sejm RP IV Kadencji, p. 21.

15 Rozporządzenie Ministra Rolnictwa i Rozwoju Wsi z dnia 9 września 2004 roku w sprawie kwalifikacji osób uprawnionych do zawodowego uboju oraz warunków i metod uboju i uśmiercania zwierząt.

16 Judgment of the Polish Constitutional Tribunal 27 November 2012 (U 4/12).

17 Joel Silver. "Zgodnie z obyczajami religijnymi (According to Religious Rights): A Dissenting Opinion on the Polish Slaughter Case". Oxford Journal of Law and Religion 2 (2014): 347-353. 
the expiration date of the challenged provision until 31 December 2012, in order to give the legislator some time to decide on implementing new EU law regulations on animal protection.

On the other hand, Art 9 (2) of the Act of 20 February 1997 on the Relationship between the State and Jewish Religious Communities in the Republic of Poland, which has been in force for over twenty years, recognises the right of Jewish communities to «care about the ritual slaughter» - which is necessary to exercise the right to perform rituals and ritual activities related to religious worship. Some conclude that this gives grounds for ritual slaughter ${ }^{18}$. It is, however, difficult to agree with this interpretation, because this provision does not authorise religious organisations to carry out ritual slaughter under the specific legal arrangements ${ }^{19}$. A similar position was taken by the Association of Jewish Religious Communities itself in the proceedings before the Constitutional Tribunal in Poland, which will be discussed below.

\section{WORK OF THE POLISH PARLIAMENT ON RE-LEGALISING RI- TUAL SLAUGHTER}

When the EU Regulation of 24 September 2009 came into force, ritual slaughter was banned in Poland and constituted a criminal offence punishable by up to two years imprisonment. The European Commission was notified about this status of ritual slaughter under Polish law on 27 December 2012. It is worth noting that the Polish government failed to inform the public about this notification in due time. Consequently, for some time in January ritual slaughter was believed to be legal ${ }^{20}$. A few months later, in mid-2013, faced with many protests of minority religious communities and meat industry operators, the Polish government tried to legalise ritual slaughter again — with no success.

18 Andrzej Czohara, Tadeusz Jerzy Zieliński. Ustawa o stosunku państwa do gmin wyznaniowych żydowskich w Polsce. Komentarz. Warszawa: Wolters Kluwer Polska, 2012, 76.

19 Piotr Stanisz. Religion and Law in Poland. Poland: Kluwer Law International, 2017, 59.

${ }^{20}$ Wojciech Brzozowski. ”Dopuszczalność uboju rytualnego w Polsce”. Państwo $i$ Prawo 5 (2013): 52-53. 
To do this, on 10 May 2013, the government submitted a bill amending the Act on Animal Protection ${ }^{21}$. The purpose was to legalise ritual slaughter carried out in accordance with "religious rites of registered religious groups», while introducing a ban on the use of so-called rotary cage. This solution was justified, among others, with the declaration to improve conditions for running business «for those entities that obtained meat in accordance with religious prescriptions». The authors of the bill came to the right conclusion that a ban on ritual slaughter made it impossible for business operators to perform their obligations resulting from contracts they had already concluded; i.e., to supply kosher meat. They believed that legalising ritual slaughter would help the Polish meat industry to compete on the EU and global market. As it can be seen, religious considerations were not decisive in this matter. In fact, they were treated only marginally in the justification to the bill.

Unfortunately, the proposed bill did not realise its goals in the area of legalising ritual slaughter exclusively for the needs of religious organisations. It contained no reference to the legal concept of «religious organisation», referring only to the relevant provisions on ritual slaughter in the EU regulation. These, however, stipulate about «religious rites», but not about legal entities set up to define and perform these rites. Nevertheless, the bill at this stage was supported by 16 different institutions that associated meat business operators. These institutions were also actively involved in the parliamentary work on the bill, which began with the first reading at the Committee on Agriculture and Rural Development on 21 May 2013. Animal rights defenders as well as representatives of several organisations of meat business operators, took part in the debate. During the debate, government representatives consistently emphasised that changes in the legislation were designed to protect the rights of religious minorities on the one hand, and the interests of businesses carrying out ritual slaughter and selling kosher meat - mainly for export, on the other hand. It should be pointed out that the MPs who opposed the bill stressed that its real purpose was to protect economic interests, rather than religious minorities, who could just as well buy imported kosher meat.

During the debate - at times very heated - the meat industry representatives argued that new regulations introducing a ban on ritual slaughter

${ }^{21}$ Rządowy projekt ustawy o zmianie ustawy o ochronie zwierząt, Sejm VII Kadencji, Druk Sejmowy nr 1370. 
would make them dependent on kosher meat exports, and would significantly jeopardise the financial position of their businesses. Ultimately, the Committee requested the Sejm to adopt the bill in a significantly expanded form. The ritual slaughter of animals was to be carried out in the presence of a authorised veterinarian, and the district veterinary officer would have to be notified about the slaughter at least three days prior to it. The notification would specify a religious rite in which the slaughter would be performed as well as the number of animals intended for killing. The bill also stipulated that the district veterinarian would keep records of ritual slaughters and submit a quarterly report to the Chief Veterinary Officer. Furthermore, the drafters provided the penalty of up to two years imprisonment for those who performed ritual slaughter in violation of these principles ${ }^{22}$.

In the course of further legislative work, the draft amendment to the Animal Protection Act was further restricted, and stipulated that for ritual slaughter to be legal, it would be necessary to obtain the consent from the district veterinary officer, and not just to notify him. In addition, it would be necessary to provide a copy of the contract or other document confirming that a specific amount of kosher meat had been ordered. Failure to provide such confirmation or the intention to slaughter the number of animals that "grossly» exceeded the contracted quantity of meat would result in the refusal to grant the consent ${ }^{23}$. This in turn was to prevent trade in kosher meat for other than religious purposes.

Despite these changes, the bill was ultimately rejected by the Sejm on 12 July 2013, which means that the amendments proposed by the government to the Animal Protection Act were not passed. The legislator did not officially explain the motives for this decision, but the media at the time pointed to the decisive influence of a lobby of environmental groups. With such attitude of the legislator, regulations on ritual slaughter were finally determined by the Constitutional Tribunal.

${ }^{22}$ Druk nr 1458. Sprawozdanie Komisji Rolnictwa i Rozwoju Wsi o rządowym projekcie ustawy o zmianie ustawy o ochronie zwierząt, http://www.sejm.gov.pl/ Sejm7.nsf/druk.xsp?nr=1458 [25.02.2020].

${ }_{23}$ Druk nr 1458-A. Dodatkowe sprawozdanie Komisji Rolnictwa i Rozwoju Wsi o rządowym projekcie ustawy o zmianie ustawy o ochronie zwierząt, http://www. sejm.gov.pl/Sejm7.nsf/druk.xsp?nr=1458-A [25.02.2020] 


\section{DECISIVE ROLE OF THE CONSTITUTIONAL TRIBUNAL IN DE- TERMINING THE LEGALITY OF RITUAL SLAUGHTER IN POLAND}

On 10 December 2014, the Constitutional Tribunal ruled that a ban on the ritual slaughter of animals carried out in a slaughterhouse following a procedure prescribed by religious rites, was unconstitutional. The case was started by the Union of Jewish Religious Communities in the Republic of Poland. The applicant claimed that the ban violated the constitutional right to freedom of conscience and religion (Article 53 (1)), including the freedom to manifest and practice one's religion (Article 53 (2)), as well as the Constitutional guarantees of the right of national and ethnic minorities to cultivate their own tradition and culture - Article 35 (1).

What is interesting for our considerations is the fact that in the statement of grounds why the ban on slaughtering animals without their prior stunning violated the right of Jewish minority to preserve their cultural identity, it was argued that the ban also infringed on the economic rights of the Jewish population. The applicant pointed out that because of the ban, Jews and restaurant owners who offered kosher menus incurred higher expenses when buying kosher meat ${ }^{24}$. Although it was not stated explicitly in the petition, it should be assumed that "higher expenses» resulted from the necessity to import meat from abroad. The complaint did not include the issue of the legality of exporting meat obtained from ritual slaughter.

In their complaint, Jewish communities requested the Tribunal to rule that the ban on ritual slaughter performed by all religious organisations with a regulated legal status (and not only those whose religious doctrines provided for ritual slaughter), violated the Constitution. This, however, according to other parties to the proceedings (i.e. the Sejm of the Republic of Poland and the Prosecutor General), was aimed not so much at ensuring Jews the right to practise their religion, but rather at making it possible to perform slaughter for economic needs, which de facto meant in a way that did not comply with the precepts of religion. In fact, at the hearing before the Tribunal, the applicant's attorney himself emphasised that the purpose of the complaint was to legalise the ritual slaughter of

${ }^{24}$ Wniosek Gmin Wyznaniowych Żydowskich w Rzeczypospolitej Polskiej z dnia 30 sierpnia 2015 r., https://ipo.trybunal.gov.pl/ipo/view/sprawa.xhtml? \&pokaz=dokumenty\&sygnatura $=\mathrm{K} \% 2052 / 13$ [d24.02.2020], p. 8 and 25. 
animals carried out by the followers of Judaism, but he pointed out that «a side effect of this could be that this ritual slaughter, unrestricted by other regulations, could lead to producing meat also for export» ${ }^{25}$.

The Constitutional Tribunal in the Judgement of 10 December 2014 (K 52/13) held that the ban on slaughter carried out in a slaughterhouse in accordance with religious rites (violation of which was punishable with criminal sanctions), was incompatible with the Constitution of the Republic of Poland. Thus, it is clear from the operative part of the judgement itself that the Polish Constitutional Tribunal rejected the possibility of performing ritual slaughter outside of a slaughterhouse (e.g., as part of the Muslim Feast of Sacrifice), but did not limit the right to practise ritual slaughter only to religious organisations with a regulated legal status. Both in the judgement did not enumerate the animal species that could be ritually slaughtered. Furthermore, it is worth noting that although the Constitutional Tribunal referred to the concept of «religious rites» that is used in regulation 1099/2009, the effect was different than the one planned by the EU legislator. This was due to the fact that the wording of the operative part of the judgement opened up the possibility of carrying out ritual slaughter in slaughterhouses, not only for religious purposes, but also for the purposes of trade.

The Tribunal, having no doubt that ritual slaughter was subject to the protection provided for freedom of conscience and religion, concluded that its legality depended on the joint fulfilment of two premises; i.e. it must be performed in a slaughterhouse in accordance with the Polish and EU law concerning the slaughter of animals and it must be performed in accordance with the precepts of a given religion. Consequently, slaughter without stunning carried out in violation of state regulations and religious precepts, is not permitted.

The Polish law, however, lacks instruments that would allow to effectively monitor the «religious character» of ritual slaughter in slaughterhouses $^{26}$. Supervision over slaughterhouses is exercised by the Veterinary

25 Stanowisko Prokuratora Generalnego z dnia 17 marca 2014 r., https://ipo.trybunal.gov.pl/ipo/view/sprawa.xhtml? \&pokaz=dokumenty\&sygnatura=K\%2052/13 [dostęp 26.02.2020], p. 39-45; Stenogram rozprawy z dnia 3 grudnia 2014 r., p. 13$14 ; 20$.

${ }^{26}$ Ewa Łętowska, Mateusz Grochowski, Aneta Wiewiórkowska-Domagalska. "Wiąże, ale nie przekonuje (wyrok Trybunału Konstytucyjnego w sprawie o uboju rytualnego). Państwo i Prawo 6 (2015): 55. 
Inspectorate, but in fact it only has the right to check whether slaughter is carried out in a slaughterhouse and whether general sanitary requirements are met. Moreover, in the light of constitutional principles on the relations between the Polish State and religious organisations, it is not possible to introduce regulations that would enable state organs to control the religious aspects of ritual slaughter. Pursuant to the Constitution of the Republic of Poland, churches and other religious organisations are autonomous and independent of the state (Article 25 (3)). In practice, this means that it is beyond the jurisdiction of any state bodies to regulate matters related to, for example, rules of religious worship ${ }^{27}$. Therefore, no state body is competent to determine what behaviours can be considered as manifestation of faith, let alone assess whether the rites are performed properly. After all, since ritual slaughter in Poland does not have to be carried out as part of religious practice in religious organisations, virtually anyone can carry it out invoking their individual religious beliefs. This in turn means that the only limitation to ritual slaughter is that is has to take place in a slaughterhouse and this is the only aspect that the state institutions can supervise.

It is clear from the reasons for Judgement of 10 December 2014 that the Polish Constitutional Tribunal was aware of these difficulties. Apart from repeated statements that the issues related to exporting meat obtained in this way were beyond the scope of adjudication, it also signalled the need to impose an obligation on the Veterinary Inspectorate to keep separate records about establishments that carry out ritual slaughter and on slaughterhouses to collect data concerning only such slaughter. At the same time, the Constitutional Tribunal recommended that state authorities collect data on the scale of the export of meat obtained from ritual slaughter. These recommendations were to «form the basis for devising a rational policy of the state, as well as for adopting detailed provisions on ritual slaughter» (point 329). It is worth noting here that the applicant in the said case repeatedly emphasised that their

27 Piotr Stanisz. "Konstytucyjne zasady określające relacje państwa z kościołami i innymi związkami wyznaniowymi: autonomia i niezależność oraz współdziałanie”. In Katolickie zasady relacji państwo-Kościót a prawo polskie, edited by Józef Krukowski, Mirosław Sitarz, Henryk Stawniak. Lublin: Towarzystwo Naukowe Katolickiego Uniwersytetu Lubelskiego, 2015, 158-170; Paweł Borecki. "Autonomia kościołów i innych związków wyznaniowych we współczesnym prawie polskim". Studia z Prawa Wyznaniowego. 15 (2012): 92-93 
intention was to review the compliance of the ban on «religious» ritual slaughter with the Constitution. In Poland, the Constitutional Tribunal shall adjudicate within the limits of the application, however - as it can be seen in this case - it decided to go beyond them. Although in the reasons for judgement, it was noted that «industrial» ritual slaughter would still be prohibited, this was not reflected in the legally binding operative part of the judgement.

To fully illustrate the impact of the Constitutional Tribunal's decision on legal regulations regarding ritual slaughter, it should be noted that a complaint that the ban on ritual slaughter did not comply with the Constitution of the Republic of Poland was also filed by the Polish Ombudsman - nearly two months after Jewish Religious Communities had done so. ${ }^{28}$ Interestingly, the Tribunal diverged from the well-established practice of giving priority to the Ombudsman's requests, and first heard the complaint brought by the religious community. This decision had far-reaching consequences, mostly due to the content of the complaint filed by the Ombudsman. In fact, he demanded that the right to carry out ritual slaughter be granted only to religious organisations whose doctrine prescribed the necessity of eating kosher meat. However, because the Tribunal had already issued the judgement, the case initiated by the Ombudsman was dismissed ${ }^{29}$.

It should be pointed out that the Polish legislator noticed the legal deficiencies following from the Tribunal's decision regarding ritual slaughter. In the 8th term of office of the Sejm, a group of MPs representing the parliamentary majority submitted a draft amendment to the Animal Protection $\mathrm{Act}^{30}$. Its purpose was to restrict the possibility of performing ritual slaughter only to the manner prescribed by religious rites of religious organisations with a regulated legal status that operated in Poland. Moreover, ritual slaughter was to be allowed only for the needs of those religious communities. However, as a result of many protests voiced by the meat industry representatives and experts, who claimed that such

28 Wniosek Rzecznika Praw Obywatelskich do Trybunału Konstytucyjnego z dnia 24 października 2014 r., https://ipo.trybunal.gov.pl/ipo/view/sprawa.xhtml?\&pokaz=dokumenty\&sygnatura=K\%2032/14, (01.03.2020 r.).

${ }_{29}$ Postanowienie Trybunału Konstytucyjnego z dnia 3 listopada 2015 roku (K 32/14).

${ }^{30}$ Poselski projekt ustawy o zmianie ustawy o ochronie zwierząt oraz niektórych innych ustaw, Sejm VIII Kadencji, znak MK-020-751/17. 
change was not in compliance with the judgement of the Constitutional Tribunal, the amendment was not proceeded with.

\section{CONCLUSIONS}

Legal regulations on ritual slaughter in Poland have evolved, shifting from the total ban on ritual slaughter to permitting such practice for the purpose of practising «religious rites», which were not clearly specified. At present, the latter is in force, this being a result of the Constitutional Tribunal's judgement and the inaction on the part of the legislature. Furthermore, any attempt to change the current law on ritual slaughter generates strong reactions from religious communities, business operators and animal rights groups. So far these discussions have been dominated by economic arguments. The analyses show that no binding decisions are made because any legislative work on this issue sparks off fierce controversies.

In such conditions, the decision of the Constitutional Tribunal that the ban on ritual slaughter was incompatible with the Constitution, opened up the possibility of performing ritual slaughter in a virtually uncontrolled way. The state authorities lack instruments to determine the «religious nature» of unstunned slaughter. Moreover, from a constitutional point of view, they may not be granted such powers. On the other hand, there are no obstacles to introducing regulations designed to control what happens with the meat obtained from ritual slaughter, and whether it is really used for religious purposes, and not the economic ones. Nonetheless, the Constitutional Tribunal - by using the wording resulting from the provisions of EU law, albeit non-congruent with Polish legal realities - in fact fulfilled the demand of some business operators who wanted ritual slaughter to be broadly allowed. Still, this is incompatible with both the Polish and EU law, as ritual slaughter may be carried out exclusively for religious practice. 


\section{REFERENCES}

Borecki, Paweł. "Autonomia kościołów i innych związków wyznaniowych we współczesnym prawie polskim". Studia z Prawa Wyznaniowego 15 (2012): 92-93.

Brzozowski, Wojciech. "Dopuszczalność uboju rytualnego w Polsce". Państwo i Prawo 5 (2013): 47-56.

Brzozowski, Wojciech. "Ubój rytualny a Konstytucja RP". In Aktualne problemy wolności myśli, sumienia $i$ religii, edited by Piotr Stanisz, Anna Maria Abramowicz, Michał Czelny, Marta Ordon and Michał Zawiślak, 41-52. Lublin: Wydawnictwo KUL, 2013.

Czohara, Andrzej \& Tadeusz Jerzy Zieliński. Ustawa o stosunku państwa do gmin wyznaniowych żydowskich $w$ Polsce. Komentar. Warszawa: Wolters Kluwer Polska, 2012.

Lerne, Pablo \& Alfredo Mordechai Rebello. "The Prohibition of Ritual Slaughtering (Kosher Shechita and Halal) and Freedom of Religion of Minorities". Journal of Law and Religion 2 (2006): 1-62.

Łętowska, Ewa, Monika Namysłowska, Mateusz Grochowski, \& Aneta Wiewiórowska-Domagalska. "Prawo UE o uboju zwierząt i jego polska implementacja: kolizje interesów i ich rozwiązanie (cz. I)". Europejski Przeglad Sądowy 11 (2013): 13-18.

Łętowska, Ewa, Mateusz Grochowski \& Aneta Wiewiórkowska-Domagalska. "Wiąże, ale nie przekonuje (wyrok Trybunału Konstytucyjnego w sprawie o uboju rytualnym". Państwo i Prawo 6 (2015): 53-66.

Różański, Mieczysław \& Piotr Szymaniec. "Debata wokół zakazu uboju rytualnego w II Rzeczypospolitej Polskiej”. Przeglad Sejmowy 1 (2020): 121-146.

Silver, Joel. "Zgodnie z obyczajami religijnymi (According to Religious Rights): A Dissenting Opinion on the Polish Slaughter Case". Oxford Journal of Law and Religion 2 (2014): 347-353.

Stanisz, Piotr. Religion and Law in Poland. Poland: Kluwer Law International, 2017.

Stanisz, Piotr. "Konstytucyjne zasady określające relacje państwa z kościołami i innymi związkami wyznaniowymi: autonomia i niezależność oraz współdziałanie". In Katolickie zasady relacji państwo-Kościót a prawo polskie, edited by Józef Krukowski, Mirosław Sitarz, \& Henryk Stawniak, 158-170. Lublin: Towarzystwo Naukowe Katolickiego Uniwersytetu Lubelskiego, 2015. 
Vellenga, Sipco. "Ritual Slaughter, Animal Welfare and the Freedom of Religion". Journal of Religion in Europe 2 (2015): 210-234.

Zoethout, Carla Maria. "Ritual Slaughter and the Freedom of Religion: Some Reflections on a Stunning Matter". Human Rights Quarterly 3 (2013): 651-672. 